\title{
Presentación de la Biblioteca Virtual de Arabistas
} On Biblioteca Virtual de Arabistas

\section{Fernando BRAVO LÓPEZ}

fernandobravolopez@yahoo.es

Recibido 19/11/2017. Revisado y aprobado para publicación 18/12/2017

Para citar este artículo: Fernando Bravo López (2017), "Presentación de la Biblioteca virtual de arabistas" en Revista de Estudios Internacionales Mediterráneos, 23, 131-133.

Para acceder a este artículo: https://doi.org/10.15366/reim2017.23.008 